THE WORLD TRADE ORGANISATION AND HUMAN RIGHTS: THE ROLE OF PRINCIPLES OF GOOD GOVERNANCE

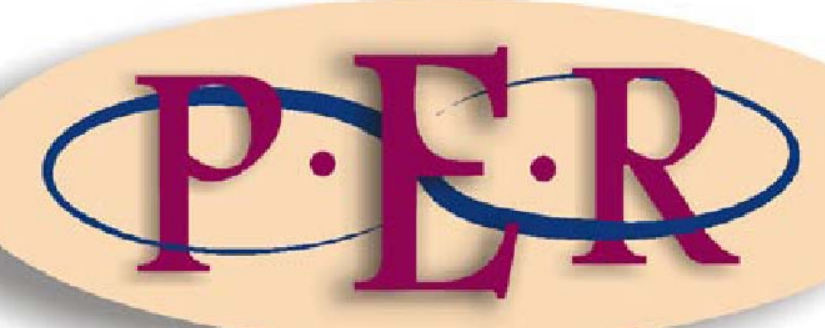

2008 VOLUME 2 


\title{
THE WORLD TRADE ORGANISATION AND HUMAN RIGHTS: THE ROLE OF PRINCIPLES OF GOOD GOVERNANCE
}

\author{
J Denkers and N Jägers
}

\section{Introduction}

Over the past decade the World Trade Organisation (WTO) has increasingly become the whipping post of those that criticise globalisation. There have been violent expressions of this critique on the streets of cities around the world. But the critique has also arisen in documents of respected international organisations. A striking example is the report on globalisation and human rights written in 2000 by two special rapporteurs of the United Nations SubCommission on Human Rights in which the WTO is described as being a 'veritable nightmare' for developing countries. ${ }^{1}$

The main critique on the WTO is that its activities have serious human rights implications and that the organisation as such does not properly address the human rights aspects of these activities. ${ }^{2}$ The present article will address the question as to the human rights implications of its activities. We will demonstrate that generally the WTO as an international organisation does not directly violate human rights. The WTO cannot be compared to other international organisations which operations may violate human rights of individuals. To make this clear we will, in the first part of this article, examine to what extent the WTO has been attributed international legal personality, that is,

* Jeroen Denkers, LLM, and Dr Nicola Jägers both work for the Centre for Transboundary Legal Development, Tilburg University, the Netherlands. This article emanates from the summer/winter course on Good Governance held in Tilburg in January 2007. This course is a cooperative initiative between North-West University in South Africa and Tilburg University, the Netherlands.

1 Oloka-Onyango and Udagama Economic, Social and Cultural Rights. Preliminary report submitted in accordance with Sub-Commission resolution 1999/8.

2 Ibid par 15. 
was given certain autonomy by its founders. Subsequently, it will be argued that even though the WTO does not violate human rights directly its activities can have implications for the enjoyment and protection of human rights.

Realisation of human rights requires an enabling environment. In other words, supportive governmental elites and bureaucrats are essential. This has given rise to the doctrine of good governance, which deals with processes aimed at creating a societal climate where human rights can be realised. The role of good governance in the promotion of human rights has been acknowledged by the Commission on Human Rights in 2000 when it stated that -

...transparent, responsible, accountable and participatory government, responsive to the needs and aspirations of the people, is the foundation on which good governance rests, and (...) such a foundation is a sine qua non for the promotion of human rights. ${ }^{3}$

In 1989, the World Bank first evolved a doctrine of good governance, which it described in the following terms:

...[g]ood governance is epitomized by predictable, open, and enlightened policy-making (that is, transparent processes); a bureaucracy imbued with a professional ethos; an executive arm of government accountable for its actions; and a strong civil society participating in public affairs; and all behaving under the rule of law. ${ }^{4}$

Most international organisations have responded to the call for good governance by adopting strategies aimed at enhancing processes of transparency, participation and accountability. The United Nations underlined the importance of the good governance doctrine in its Millennium Declaration. In paragraph 13 it is stated that the fight against extreme poverty and towards securing development depends inter alia on:

...good governance at the international level and on transparency in the financial, monetary and trading systems. We are committed to an 
open, equitable, rule-based, predictable and non-discriminatory multilateral trading and financial system. ${ }^{5}$

There is now a sprawling body of literature on the concept of good governance. Various definitions exist and many different principles can be identified. 6 The common principles that can be deduced from the various definitions are transparency, accountability, participation, rule of law, effectiveness, efficiency, proportionality, consistency and coherence. In this article, we concentrate on the good governance principles of transparency and participation in relation to the WTO. These principles are, as will be explained, ${ }^{7}$ of particular importance for this organisation. Even though, the WTO as an organisation does not directly violate human rights we will make clear that as the exponent of trade liberalisation it does have a role to play when it comes to human rights.

We argue that a further incorporation of good governance principles will help the WTO achieve its ultimate aim which as can be deduced from the preamble of the agreement establishing the WTO, is not trade liberalisation. According to the preamble the Member States of the WTO -

...[r]ecognizing that their relations in the field of trade and economic endeavour should be conducted with a view to raising standards of living, ensuring full employment and a large and steadily growing volume of real income and effective demand, and expanding the production of and trade in goods and services, while allowing for the optional use of the world's resources in accordance with the objective of sustainable development, seeking both to protect and preserve the environment and to enhance the means for doing so in

5 GA Res 55/2, 8 September 2000.

6 Eg, good governance according to the European Commission means "rules, processes and behaviour that affect the way in which powers are exercised at European level, particularly as regards openness, participation, accountability, effectiveness and coherence". See Commission of the European Communities http://eur-lex.europa.eu/ 24 Jun. The United Nations Economic and Social Commission for Asia and the Pacific distinguishes the following characteristics of good governance: "It is participatory, consensus oriented, accountable, transparent, responsive, effective and efficient, equitable and inclusive and follows the rule of law. It assures that corruption is minimised, the views of minorities are taken into account and that the voices of the most vulnerable in society are heard in decision-making. It is also responsive to the present and future needs of society." See UNESCAP http://www.unescap.org/ 16 Jun.

7 See par 3.1. 
a manner consistent with their respective needs and concerns at different levels of economic development. ${ }^{8}$

In other words, free trade is not an aim in itself but a means to achieve the aim of sustainable development. Given the role of principles of good governance in the realisation of human rights, good governance also plays an important role in realising this aim.

\section{What role does the WTO play regarding human rights?}

\subsection{The World Trade Organisation: a brief overview}

The WTO was established in 1995 as the successor to the General Agreement on Tariffs and Trade (GATT). The GATT, which initially was intended as a temporary framework, had served as the institutional basis for the world's multilateral trade system for 47 years. However, by the 1980s the system needed a thorough overhaul. Over the years the multilateral trading system had become more and more liberal through successive rounds of trade negotiations. World trade had become far more complex: global economic integration was underway and trade in services which became of interest to an increasing number of countries was not covered by GATT. ${ }^{9}$ As of that moment the WTO was established as the new institutional foundation of the multilateral trade system. As stated in the introduction, the preamble to the agreement proves that free trade is not the ultimate goal of the organisation. Rather, the WTO should be seen as an organisation that facilitates the reduction of trade barriers and pursues equality in market access between members. ${ }^{10}$

8 Emphasis added. Marrakesh Agreement establishing the World Trade Organization, United Nations Treaty Series, 33 International Legal Materials 1125 (1994), entered into force 1 January 1995.

9 WTO http://www.wto.org/english/thewto e/whatis e/tif e/understanding e.doc 4 May.

10 Hoekman and Kostecki Political Economy 13. 
The organisation has been described as being a code of conduct as well as a negotiating forum. ${ }^{11}$ The WTO offers States a forum to negotiate on international trade rules that regulate their trade policies. In this respect, the preamble to the agreement establishing the WTO holds that its Member States should contribute to the WTO -

objectives by entering into reciprocal and mutually advantageous arrangements directed to the substantial reduction of tariffs and other barriers to trade and to the elimination of discriminatory treatment in international trade relations.

But if it seems at first glance that the WTO is not much more than a negotiation forum and a code of conduct, then how does this relate to the human rights critique that the organisation is often subject to? In an attempt to answer this question the following section will focus on the question to what extent the organisation bears rights and duties under international law in detachment from its members. In essence, this is the question to the autonomy given to it by its founders. Subsequently, the question to the human rights impact of the described autonomous operations of the organisation will be dealt with.

\subsection{The international legal personality of the WTO}

Before human rights accountability of an international organisation can be established it is first necessary to examine its position in public international law. Legally speaking, international organisations can only be held accountable if they have actual duties in international law, which they violate rather than the Member States acting as a collectivity. ${ }^{12}$ In other words, does an entity bear separate rights and duties under international law? States are the traditional subjects of international law and have full legal personality. International organisations, however, are created by these original subjects. They are attributed rights and duties by States. Therefore, organisations which have

11 Ibid $\mathrm{p} 3$.

12 Amerasinghe Principles 78. 
been attributed such international legal personality are frequently defined as ancillary subjects of international law. ${ }^{13}$

In order to determine to what extent an international organisation such as the WTO is an international legal person it is necessary to examine to what extent it is a distinct entity from its Member States. Has it been given certain autonomy by its creators? The WTO is often referred to as a member-driven organisation. As was said earlier, it is a negotiation platform where States negotiate trade rules that they will have to implement accordingly. It is States that are bound by human rights obligations in the negotiation and implementation process. Legally speaking, they are responsible if they violate human rights in the implementation of trade rules that they have negotiated. If States, for instance, would not be allowed under WTO law (which they have negotiated) to ban dangerous products which may jeopardise public health it is the importing State that would be accountable for a violation of the right to health. It has even been argued that developed States may be accountable for certain trade affecting policies such as subsidisation that may have negative impacts on development in developing countries. ${ }^{14}$ It is for this reason that States make human rights impact assessments in the process of negotiating new international trade rules.

\subsection{How does the WTO affect human rights?}

The foregoing illustrates that it is not the organisation as such that is responsible for human rights violations in these processes but rather its Member States. This may be different in other international organisations with more autonomous powers such as the International Monetary Fund (IMF) of which its operations and policies may have decisive effects on the lives of people. ${ }^{15}$ In contrast to IMF decision-making, decisions within the WTO are taken by consensus. ${ }^{16}$ Yet, also within the WTO there are parts of the organisation that have been attributed certain autonomy and whose activities

13 Cassese International Law 71.

14 See for instance, 3Dthree http://www.3dthree.org/ 22 Jun.

15 See Skogly Human rights obligations.

16 See supra n 10 at 41. 
may have human rights implications. First of all, the WTO dispute settlement mechanism. Rulings of the panels and the Appellate Body are binding and the Member States have a duty to comply with its rulings. The position of this body in detachment of its members gives it certain rights and obligations under international law. Because its binding judgments may compel a state to adopt one policy rather than another, its decisions may have an impact on state policies to protect human rights. This particular matter will be dealt with in the next section.

Dispute settlement is not the only activity of the organisation that may have human rights implications. Two more activities that the WTO exercises with certain autonomy from its Member States and which may have human rights implications will be discussed here. Although these activities do not bind the Member States like the WTO dispute settlement mechanism they may have a human rights impact in a normative sense. It concerns the Trade Policy Review Mechanism (TPRM) and technical assistance. Trade Policy Review is the regular surveillance of national trade policies by the Trade Policy Review Body, which is meant to enhance the transparency of members' trade policies and examine the impact of such trade policies and practices of members on the trading system. The review takes place every two, four or six years depending on the Member State's share of world trade and consists of a report prepared by the government concerned and by the WTO Secretariat. ${ }^{17}$ The reviews are not legally binding. It is explicitly stated that the mechanism is designed only to increase transparency and understanding and is not intended to impose new policy commitments on the Member States. Another activity of the WTO concerns technical assistance such as training programmes meant to help developing and least developed countries to adjust to WTO rules. ${ }^{18}$

None of these activities would directly violate human rights for which the WTO can be held accountable. However, non-legally binding statements where

18 Id and WTO http://www.wto.org/ 22 Jun. 
national policies are evaluated in isolation from non-trade issues may have a normative impact. The fact that the WTO should not be considered to be disconnected from human rights issues becomes especially apparent in the rulings of the WTO dispute settlement mechanism, which may require a state to adapt its policies for the protection of human rights. Therefore, this issue will be dealt with in more detail in the next section.

\subsection{WTO dispute settlement and its human rights impact}

As was stated above, it is hard to think of an example where the WTO dispute settlement mechanism would directly violate human rights. Basically, this organ examines if a state's conduct is in conformity with obligations under the WTO agreements when a complaint is received. It thus examines whether certain trade measures are allowed under WTO law. In this way its judgments may have an impact on human rights protection. Trade measures are often used to secure compliance with human rights. In this respect, 'outwardly-directed' trade measures as opposed to 'inwardly-directed' trade measures can be distinguished. ${ }^{19}$ If it concerns the latter type of measures, a state adopts trade measures in order not to violate its own human rights obligations. A state, for instance, may want to restrict the import of asbestos products in order to protect public health within its own territory. Obviously, it is the most common form of trade measures for the protection of human rights since states are primarily obliged to respect, protect and fulfil human rights obligations within their own jurisdiction. ${ }^{20}$

However, it is also feasible that the WTO dispute settlement mechanism at some point will be asked to rule on the lawfulness of trade restrictions for the protection of human rights elsewhere. For trade measures have been a commonly used means by states to make other states comply with their human rights obligations in international law.

19 Charnovitz 1998 Virg J of Int'l L 689-746.

20 See Shue Basic Rights; Alston and Tomasevski (eds) Right to Food; Eide Right to Adequate Food; Maastricht Guidelines 1998 Human Rights Quarterly 691-705. 
Such outwardly-directed trade measures are either of the positive or negative kind. They can generally be divided into trade concessions or trade restrictions. An example of the former is the General System of Preferences (GSP) the EU and the US have to grant non-reciprocal trade benefits to developing countries under the condition that they comply with an agreed set of human rights. Granting benefits to one country over another, which would usually be in violation of the GATT, ${ }^{21}$ is permitted under the enabling clause if the benefit is granted to a developing country. ${ }^{22}$ The question if these benefits may be subject to certain conditions, such as respect for human rights, is not entirely clear however. WTO case law suggests that preferential tariff treatment must be non-discriminatory in that similar benefits are accessible to similar situated developing countries. ${ }^{23}$

When it comes to trade restrictions, such as selective procurement policies, import or export prohibitions, tariffs et cetera, this may be problematic. A brief look into state practice suggests that the use of trade restrictions to induce other states to comply with their international obligations is not uncommon in international law. ${ }^{24}$ The US, for instance, in 1978 adopted a trade embargo that violated their GATT obligations against Uganda in response to genocide committed by the Ugandan government. ${ }^{25}$ In April 1982, when Argentina took control over part of the Falkland Islands, the European Community, Australia, New Zealand and Canada adopted trade sanctions, including a temporary import barrier against Argentinean products in violation of their GATT obligations. Another example is the rather unique case of Burma (Myanmar). Here, the International Labour Conference for the first time in its history recommended states, employers and workers to

21 It concerns the most-favoured-nation clause which means that if a Member State grants a trade benefit to one state it should grant the same benefit to all other Member States.

22 GATT BISD 26S/203, adopted 28 November 1979.

23 WTO Doc WT/DS246/AB/R, adopted on 20 April 2004, par 129, 187-189.

24 Crawford Third Report on State Responsibility 14. Crawford cites the Uganda Embargo Act.

25 Ibid. Note that in this case the US did not rely on GATT exceptions but on its obligations under general international law. 
review (...) the relations they may have with the Member State concerned and take appropriate measures to ensure that the said Member cannot take advantage of such relations to perpetuate or extend the system of forced or compulsory labour referred to by the Commission of Inquiry and to contribute as far as possible to the implementation of its recommendations. ${ }^{26}$

As a result of the ILC recommendation the US adopted the Burmese Freedom and Democracy Act which prohibits all imports from Burma. ${ }^{27}$

It seems that states, when adopting such trade restrictions, often claim that they are obliged to do so under general international law. This raises the question if such legal basis can be found in general international law. In this respect article 41(2) of the Articles on States Responsibility (ASR) as drafted by the International Law Commission (ILC) may be of particular relevance. ${ }^{28}$ It holds that states are under a negative obligation not to recognise as lawful a situation created by a serious breach of a peremptory norm and not to render aid or assistance in maintaining that situation. ${ }^{29}$ The ILC finds confirmation in Security Council resolutions "prohibiting any aid or assistance in maintaining the illegal apartheid regime in South Africa or Portuguese colonial rule". ${ }^{30}$ More importantly, the ICJ also explicitly referred to the existence of such obligation in the Israeli Wall case. ${ }^{31}$

26 Resolution Concerning the Measures Recommended by the Governing Body under Article 33 of the ILO Constitution on the Subject of Myanmar, $88^{\text {th }}$ session, June 2000, par 1(b). Also see Maupain Upholding Workers' Rights 85-142; Vandaele International Labour Rights 629.

27 Burmese Freedom and Democracy Act HR 2330, 2003.

28 Although these articles do not constitute a binding legal instrument as such it may be considered an influential source since they are an attempt to reflect state practice.

29 Gattini makes clear that the ILC through these obligations "gave substance to the fundamental idea of the social ban on and isolation of the outlaw". Note that art 16 deals with assistance in the commission of an internationally wrongful act. In contrast, art 41 "deals with conduct 'after the fact' which assists the responsible State in maintaining a situation opposable to all States in the sense of barring erga omnes the legality of a situation which is maintained in violation of international law". Gattini 2002 Eur J Int'l L 1181-1199.

30 UN http://untreaty.un.org/ 7 May at 291.

31 ICJ Legal Consequences of the Construction of a Wall in the Occupied Palestinian Territory Advisory Opinion 9 July 2004 http://www.icj-cij.org/ 12 Jan at par 159. 
It seems that states in realising this obligation may violate other norms of international law such as international trade law. This can be illustrated by the abovementioned example of the US trade embargo in 1978 adopted against Uganda in response to genocide committed by the Ugandan government. The US claimed that it "should take steps to dissociate itself from any government which engages in the international crime of genocide". ${ }^{32}$ Admittedly, maintaining trade relations in such cases would be tantamount to rendering aid or assistance in maintaining the situation created by the ongoing breach. As the International Confederation of Free Trade Unions (ICFTU) held with regard to systematic and widespread forced labour in Burma:

It is impossible to conduct any business relationship in Burma without directly or indirectly supporting the Burmese military dictatorship which is responsible for the extensive use of forced labor, as well as other serious human and trade union rights violations. $^{33}$

To sum up, it has been demonstrated that under general international law on state responsibility, states have the obligation not to render aid or assistance with regard to a serious breach of a peremptory norm. The substance of this obligation however, may not always be clear. In the case of Burma it is evident that the Burmese regime is directly responsible for the serious violation of international law. Any support to that regime would therefore boil down to a violation of the obligation not to render aid. This may, however, be different if it is a non-governmental actor rather than a government that does not respect a peremptory norm. When it comes to violations of labour rights it is often corporations that do not respect these norms rather than the state. This raises the question if the obligation not to render aid or assistance can also be fulfilled by tailored sanctions against corporations or certain industries that do not

32 Crawford Third Report on State Responsibility 14. Crawford cites the Uganda Embargo Act. Note that in this case the US did not rely on GATT exceptions but on its obligations under general international law.

33 See Jägers quoting a press release of the ICFTU of 15 November 2001. Jägers Corporate Human Rights Obligations 94. 
respect such norms. One can think of import prohibitions targeted against products. In the words of Vázquez:

Are countries required to prohibit all imports from the exporting country (even goods not made with child labor)? After all, a total embargo is even more likely to induce the exporting country to prohibit child labor than is a ban on the importation of one product. On this view, failure to impose a complete embargo would be tantamount to 'encouragement' or 'support' of child labor. ${ }^{34}$

It can be concluded that states are under the obligation not to render aid or assistance in the case of a serious violation of a peremptory norm. It is open for further debate whether this obligation stretches beyond the adoption of tailored sanctions.

What seems clear is that if states are under such obligation it is feasible that the WTO 'judiciary' 35 may have to decide on the legality of such measures under WTO law. ${ }^{36}$ In fact, the chances that this will happen have increased with the establishment of the WTO. In the old GATT system trade rules were often bent and even broken because no effective dispute settlement system existed. Rulings could be easily blocked by one of the parties to a dispute. Hence, states could, arguably, too easily adopt trade sanctions in the abovementioned examples of Uganda and Argentina under the old GATT system. This changed in 1995 with the inception of a more effective dispute settlement system. ${ }^{37}$

34 Vázquez 2003 JIEL 797-839.

35 Strictly speaking the term 'judiciary' is not correct when referring to WTO panels and AB. The panels are established $a d$ hoc and the legal findings of both the panels and the $A B$ are recommendations that need to be adopted by the Dispute Settlement Body in order for them to become binding. Nevertheless, the independent functioning of the panels and the $A B$ in practice gives them a judicial character in the international law sense. Therefore the term judiciary will be used in this article. See Pauwelyn Conflict of Norms 442.

36 It is worth noting that Maupain claims that the US considered the chance that Myanmar would go to the WTO to complain rather small in view of similar sanctions adopted by other countries. Supra n 26 at 114.

37 Under the old GATT a procedure for dispute settlement already existed. Yet, this system did not prove to be very effective. Rulings could be easily blocked because they could only be adopted by consensus. Moreover, many cases dragged on for a long time inconclusively because of the lack of fixed timetables. Therefore, the Understanding on Rules and Procedures Governing the Settlement of Disputes was adopted in order to 
In the light of this it is worth mentioning that the question whether the implementation of selective public procurement policies is in violation of WTO law has already been raised with regard to legislation adopted by Massachusetts which prohibited state agencies from contracting with corporations doing business in Burma. ${ }^{38}$ The European Union claimed that this policy was in violation of the WTO Government Procurement Agreement ${ }^{39}$ as it imposed conditions that were not essential to fulfil the contract and were based on political instead of economic considerations. ${ }^{40}$ The EU therefore requested consultation in the WTO. ${ }^{41}$ The Massachusetts law was also challenged in the domestic courts of the United States by the National Foreign Trade Council (NFTC), a coalition of corporations, which claimed that the Massachusetts law was unconstitutional as it infringed on the federal governments' exclusive authority to regulate foreign affairs. ${ }^{42}$ The case went to the Supreme Court, which ruled in favour of the NFTC. The EU then decided to withdraw their request for consultations and the case did not proceed any further within the WTO. As a result the WTO dispute settlement system has not yet had the opportunity to address the question whether public procurement policies that are selective in view of protecting human rights abroad are in violation of WTO law.

structure the system. It introduced deadlines set in various stages of the procedure and it became impossible for a losing country to block a ruling.

38 Act of June 25th, 1996, ch 130, 1, 1996, Mass Acts 210, codified at Mass Gen L ch 7 22G22M.

39 Agreement on Government Procurement, opened for signature 15 April 1994 (entered into force on 1 January 1996), 1915 UNTS 103. Public procurement is exempted from the GATT. Contrary to the GATT the Agreement on Public Procurement is a plurilateral treaty and therefore only enforceable against Member States, which currently are Canada, European Communities (including its 25 Member States: Austria, Belgium, Cyprus, Czech Republic, Denmark, Estonia, Finland, France, Germany, Greece, Hungary, Ireland, Italy, Latvia, Lithuania, Luxemburg, Malta, Netherlands, Poland, Portugal, Slovak Republic, Slovenia, Spain, Sweden, United Kingdom), Hong Kong China, Iceland, Israel, Japan, Korea, Liechtenstein, Netherlands with respect to Aruba, Norway, Singapore, Switzerland, and United States.

40 The EU and Japan considered this to be a violation of articles VIII (b), X and XIII of the WTO Agreement on Government Procurement. WTO Doc WT/DS88/1, GPA/DS2/1 United States - Measure Affecting Government Procurement, Request for Consultation by the 41 Id. European Communities, June 26, 1997.

42 National Foreign Trade Council v Baker 26 F Supp 2d 287, 291 (Mass 1998). 
The foregoing proves that it is not unlikely that the WTO judiciary at some point will be asked to rule on the legality of such trade measures. If it would decide that the measure taken in view of protecting fundamental norms are in fact a violation, WTO law would constitute an obstacle to the enforcement of these fundamental norms.

\section{What can the WTO do?}

As was discussed above, when comparing the WTO to many other international organisations, it should be concluded that the WTO only acts independently from its Member States in the field of Trade Policy Review, technical assistance and dispute settlement and only in the case of the latter can the organisation be an obstacle for the protection of human rights from a legal perspective. It should however not be concluded that the WTO has no relevance for human rights beyond the activities discussed here. Even though the WTO as an international organisation does not directly violate human rights, the way the organisation works severally impacts the trade liberalisation agenda, which can have adverse effects on the promotion and protection of human rights.

The approach of the WTO is an all or nothing approach -the so-called 'Single Undertaking'- meaning that all WTO rules apply to all members and all WTO members must participate in (almost) all WTO treaty regimes. This approach limits the room for non-trade issues. Moreover, as pointed out by Howse,

The fact that the WTO is based on consensus decision-making by delegates of Member governments has been invoked to suggest that there is no need for further accountability of the activities of the WTO as an institution. This ignores the considerable role of the Secretariat as well as particular delegates assigned for example as chairs of negotiating or other committees in the WTO to set agendas, "frame" the way that issues are discussed, make judgments that have normative impact about the meaning of WTO rules, and even (for example), the case of Secretariat reports with respect to the Trade 
Policy Review Mechanism (TPRM) or technical assistance) to judge and advise the policymakers of individual WTO Members. ${ }^{43}$

In other words, the way the most important institution advocating trade liberalisation goes about this process is vital. It is necessary that the WTO is receptive to human rights concerns to ensure that in the process of trade liberalisation ample room is provided for human rights considerations.

\subsection{The WTO and principles of good governance}

What has the WTO done so far to contribute to an environment conducive to human rights? In other words what role do the principles of good governance play within the organisation? And what further steps can the WTO take?

As discussed in the introduction, the doctrine of good governance in international organisations deals with processes that enhance transparency, participation and accountability. In this article two principles will be discussed that, arguably, are particularly relevant in the context of the WTO. These are the principles of participation and transparency.

The principle of participation is of fundamental importance for any international organisation. It is a mistake to think that a state can adequately represent all voices. Increasingly, people join together out of concern for a certain topic that they feel might be better represented by an NGO across geographical and political borders than by their own government. Civil society can bring to the fore topics that would otherwise escape attention. The principle of participation is especially relevant for the WTO in light of the often voiced criticism that, notwithstanding the fact that legally all states have equal rights given the principle of consensus voting, in practice a couple of selected countries hold all the power. These countries set the agenda and negotiate the bargains that others are expected to take. This effect is strengthened by the WTO structure as a Single Undertaking referred to earlier. Furthermore, meaningful participat- 
ion requires transparency. The WTO is often perceived as a rather arcane organisation. For civil society and others to participate in a meaningful manner they need to know what is going on. An often-voiced criticism towards the WTO is the secrecy especially surrounding the proceedings of the dispute settlement mechanism. Enhancing transparency and participation in the institutional processes of the WTO will also contribute to other good governance principles such as accountability. ${ }^{44}$

The following section will discuss what so far has been done in the WTO concerning the principles of participation and transparency.

\subsubsection{The principle of participation}

The WTO system is often considered a 'closed' system where non-state actors such as multinational corporations and NGOs are barred from participation. Beside non-state actors, international organisations also encounter problems trying to obtain access to discussions. ${ }^{45}$ The intention appears to have been different with the original International Trade Organisation (ITO) where during the negotiations a role for NGOs was envisaged. The idea was that NGOs would maintain regular contact with the ITO secretariat, receive unrestricted documents, propose agenda items and participate as observers and occasional speakers at conferences. ${ }^{46}$ The ITO, however, never came into being and the position of non-state actors at the GATT and successor the WTO is generally perceived as minimal. Is this perception indeed accurate? The legal provision governing the participation of NGOs in the WTO is article V (2) of the Final Act Uruguay Round (Marrakech agreement) ${ }^{47}$, which reads

44 In a strict legal sense it is not appropriate in the context of the WTO to use the term accountability. As discussed in s 2, the WTO differs from most other international organisations given the limited independence from its Member States. Accountability therefore lies primarily with these states. However, if accountability is taken as a broader concept where the organisation is required to render account for its actions towards its constituencies this good governance principle is also relevant in the light of the present article.

45 Howse 2003 Eur LJ 497.

46 Loy Public Participation 116; Charnovitz 1996 U PA J Int'I Econ L 331-357.

47 The Agreement establishing the WTO, supra n 8. 
[t]he General Council may make appropriate arrangements for consultation and co-operation with non-governmental organizations concerned with matters related to those of the WTO.

Compared to the United Nations, where NGO participation is generally considered to be well established ${ }^{48}$ based on article 71 of the UN Charter, ${ }^{49}$ this provision potentially is far-reaching as it also speaks of co-operation and not merely consultation.

What has the WTO done to give effect to this provision? In 1996, the General Council drew up Guidelines for Arrangements on Relations with NonGovernmental Organisations. ${ }^{50}$ According to these guidelines, the Secretariat was given the task of playing

...a more active role in its direct contacts with NGOs who, as a valuable resource, can contribute to the accuracy and richness of the public debate. ${ }^{51}$

In general, the Guidelines are perceived as containing only marginal commitments for informal dialogue. ${ }^{52}$ The Guidelines contain the following firm statement:

[T] here is currently a broadly held view that it would not be possible for NGOs to be directly involved in the work of the WTO or its meetings. Closer consultation and cooperation with NGOs can also be met constructively though appropriate processes at the national level where lies primary responsibility for taking into account the

48 This should not be taken to imply that no problems exist. For the threats to NGO participation in the UN see Kamminga Evolving Status of NGOs 93-111.

49 Art 71 reads: "The Economic and Social Council may make suitable arrangements for consultation with non-governmental organisations which are concerned with matters within its competence (...)".

50 WTO Doc WT/L/162 Decision adopted by the General Council on 18 July 1996, July 23 ${ }^{\text {rd }}$ 1996.

51 Part IV of the Guidelines.

52 Willetts Representation of private organizations 53; International Centre for Trade and Sustainable Development Public Participation in the International Trading System. Accreditation Schemes and Other Arrangements for Public participation in International Fora. A contribution to the debate on WTO and transparency, International Centre for Trade and Sustainable Development, November 1999. 
different elements of public interest which are brought to bear on trade policy-making.

Nevertheless, in recent years, the WTO has undertaken a number of important activities to strengthen the informal participation of the public at large and NGOs in particular. ${ }^{53}$ The WTO has reached out to NGOs by organising symposia and day-to-day contact between the WTO secretariat and NGOs. In 1998, a programme of regular meetings between the External Relations Division and NGOs on the work of WTO committees and working groups was set up. A special section for NGOs issues was created on the WTO website and the WTO secretariat circulates NGO position papers. In 1996, the General Council decided to permit NGOs attendance at the WTO Ministerial Conference in Singapore. ${ }^{54}$ A practice has developed of providing NGOs that "are concerned with matters related to those of the WTO" a kind of accreditation to attend plenary sessions. ${ }^{55}$ NGOs cannot attend any of the committees.

In the dispute settlement system the possibilities of participation by NGOs are limited. The WTO dispute settlement system is an inter-state system; only Member States can bring a case before the Dispute Settlement Body (DSB). ${ }^{56}$ Other WTO members with a substantial interest in the dispute may intervene as third parties. ${ }^{57}$ Formally, therefore, there is no room for NGOs to participate in the legal proceedings of the WTO judiciary. However, in practice Member States frequently bring cases before the WTO DSB after considerable pressure from non-state entities such as multinational corporations. It has been stated that non-state entities representing business interests therefore have indirect

53 For a survey of this history see Charnovitz 2000 Fordham Int'l LJ 173-216.

54 According to the website of the WTO 108 NGOs took part in this Ministerial Conference.

55 The number of NGOs participating in the ensuing Ministerial Conferences amounted to: 128 in Geneva (1998); 686 in Seattle (1999); 370 in Doha (2001); 795 in Cancun (2003) and 821 in Hong Kong (2005). Information available on the WTO website.

56 The WTO Agreement Annex 2 Understanding on Rules and Procedures Governing the Settlement of Disputes 1869 UNTS 401, 33 ILM 1226 (1994) (DSU).

57 Art 10, par 2 Annex 2, WTO Agreement. 
access to the WTO Dispute Settlement Body. ${ }^{58}$ Nevertheless, only states have direct access to the dispute settlement system.

In several cases, WTO panels and the Appellate Body have been confronted with un-requested amicus curiae submissions in the course of their proceedings mostly from NGOs with an environmental interest and from business associations. Neither the Dispute Settlement Understanding (DSU) nor the Working Procedures for Appellate Review contain a provision on whether or not unsolicited amicus curiae briefs are admissible in the WTO proceedings. However, according to article 13 DSU, WTO panels do have the authority "to seek information and technical advice from any individual or body which it deems appropriate". Based on this provision and the fact that panels are required to make an objective assessment (art. $11 \mathrm{DSU}$ ), the Appellate Body has slightly opened the doors for NGO participation in the form of amicus curiae submissions. The first time a WTO panel motivated a decision on whether it had legal authority to accept amicus curiae briefs was in 1998 in the US-Shrimp case $^{59}$ In the course of the proceedings, the WTO panel sought advice from a group of experts. It also received two amicus curiae briefs from NGOs. ${ }^{60}$ The panel, in a restrictive interpretation of its mandate, decided it had no authority to take these briefs into consideration, as it had not requested such information. ${ }^{61}$ However, on appeal the Appellate Body overturned the decision of the panel stating that accepting non-requested information from NGO sources is not incompatible with the DSU and observed that panels have the discretionary authority either to accept or to reject information, whether requested or not. ${ }^{62}$

58 For more on this influence of corporations on the proceedings before the WTO judiciary, see Reinisch and Irgel 2001 Non-State Actors and International Law 137-138; Schaffer Defending Interests; Van den Bossche Hoe kan het beter? [How can it be improved? Prevention of trade wars by the WTO.]

59 WTO Doc WT/DS58/R United States - Import Prohibition of Certain Shrimp and Shrimp Products 15 May 1998 (hereinafter: Shrimp/Turtle case), par 7.8. In two cases in 1996 (on Hormones and Gasoline) NGOs also submitted amicus curiae briefs but the WTO panels rejected these without further explanation.

60 The Center for Marine Conservation and the Center for International Environmental Law, both based in the US

61 Shrimp/Turtle case, supra n 59, par 7.8.

62 WTO Doc WT/DS58/AB/R Shrimp/Turtle Case Report of the Appellate Body 12 October 1998, par 108-109. 
Since this decision, WTO panels have been confronted with unsolicited submissions by NGOs on a number of occasions. In most cases, the panels have decided not to accept such briefs. In various cases, panels have indicated a preference for amicus curiae briefs to be annexed to the submissions of the parties to the dispute, therewith using the parties as a 'filter'. ${ }^{63}$

Amicus curiae participation has also been allowed at the appellate level by the Appellate Body which believes such a right flows from its broad authority to adopt procedural rules, provided they do not conflict with the DSU or the covered agreements. ${ }^{64}$ The discretion to accept unsolicited amicus curiae submissions lies with the Appellate Body and so far none have been considered to be pertinent or useful.

NGOs participating in the WTO dispute settlement procedures as 'friends of the court' have caused considerable controversy. Member States reacted fiercely to the decision to allow for amicus curiae participation. On behalf of the Informal Group of Developing Countries, Egypt requested an extraordinary meeting of the WTO General Council. ${ }^{65}$ The vast majority of the Member States alleged that the Appellate Body trespassed its own mandate and had unduly acted as a legislator. Only the United States, New Zealand and Switzerland supported the Appellate Body decision to allow for amicus curiae submissions.

$63 \mathrm{Eg}$, in the Softwood lumber case the panel received an amicus brief from the NGO Northwest Ecosystem Alliance. In the report of the Panel of 22 March 2004 (WTO Doc WT/DS277/R) the panel states (in a footnote): "Having carefully considered the question of how to treat that communication, and any further such communications that might be received, and in the light of the absence of consensus amongst WTO members on the question of how to treat amicus submissions: we decided not to accept unsolicited amicus curiae submissions in the course of this dispute" (n 75). The Panel went on to state that arguments that were raised by amici will only be examined to the extent they are taken up in the written submissions of the parties to the dispute.

64 Art 17.9 DSU. The AB first considered this issue in the case United States - Imposition of Countervailing Duties on Certain Hot-Rolled Lead and Bismuth Carbon Steel Products originating in the United Kingdom WTO Doc WT/DS138/AB/R adopted 7 June 2000, DSR 2000:V, 2601, par 43.

65 WTO Doc WT/GC/M/60 General Council, minutes of the meeting of 22 November 2000. 
It can be concluded that NGOs acting as amicus curiae - at least in theory have found their way into WTO proceedings. However, despite this in practice most submissions are rejected with little or no explanation. This has, nevertheless, not stopped NGOs from acting as friends of the court.

\subsubsection{The principle of transparency}

To be able to participate in the WTO it is necessary that the organisation is transparent. What has the WTO done over the years to increase transparency?

A number of Member States, notably the United States during the Clinton administration, have pushed an agenda for reform in the area of transparency urging for greater transparency within the WTO. ${ }^{66}$ The WTO has responded to demands for greater release of information concerning WTO policymaking, most notably by constructing an elaborate website. In 2002, a long debated decision was taken on earlier de-restriction of documents. ${ }^{67}$ Negotiating proposals are now public; they have generally been made accessible and can therefore be publicly scrutinised. However, the idea of transparency does not seem to have been mainstreamed throughout the whole organisation. Howse mentions as an example the negotiations on sectoral commitments that remain confidential. $^{68}$

Accusations of secrecy have been targeted especially at the dispute settlement system where proceedings before the panels and the Appellate Body take place behind closed doors. A proposal to open up panel and Appellate Body procedures was already put forward by the United States in 1999. In August 2005 , the DSB decided at the request of the parties involved in the EC-

66 See, eg, the statement made by president Clinton at the WTO Ministerial Meeting in Geneva on 18 May 1998; Loy supra n 46 at 113-136.

67 WTO Doc WT/L/452 Procedures for the de-restriction and circulation of WTO documents 16 May 2002.

68 Howse supra n 43 at 883-884. 
Hormones dispute ${ }^{69}$ that the proceedings before the panel would be open to the public through a closed circuit TV Broadcast. Meetings with third parties remained closed, as not all parties agreed to have the proceedings open to the public. This was the first time that the WTO agreed to partly open proceedings to the public. The second time - and at the time of writing - last time that the WTO agreed to public panel proceeding was in the case of United States Measures affecting Large Civil Aircraft in March 2007. ${ }^{70}$ This was again the result of explicit request by the parties in the case, the EC and the US.

\subsection{The Sutherland report}

On the occasion of the tenth anniversary the WTO published the report entitled The Future of the WTO - known as the Sutherland report after the chairman of the commission that drafted the report - which reflects on the state of the WTO and the institutional challenges ahead. ${ }^{71}$

One entire chapter of the nine-chapter Sutherland report is devoted to 'transparency and dialogue with civil society'. ${ }^{72}$ This demonstrates the importance of this relationship for the future of the WTO. Nevertheless, it might be telling that, as pointed out by several observers ${ }^{73}$ that the report was drafted by 'insiders' without wide consultation and deliberation. The report in general reflects a rather guarded, defensive approach and has not generated the public discussion hoped for.

The report draws the conclusion that "much has been achieved in the area of external transparency over the past few years" ${ }^{\prime 4}$ and recommends that the

69 WTO Doc WT/DS320 United States - Continued Suspension of Obligations in the ECHormones Dispute, WTO Doc WT/DS321 Canada - Continued Suspension of Obligations in the EC-Hormones Dispute, 27-28 September 2006 and 2-3 October 2006.

70 WTO Doc WT/DS316 United States - Measures affecting Trade in Large Civil Aircraft 2021 March 2007.

71 Report by the Consultative Board to the Director-General Suachai Panitchpakdi, see Sutherland et al http://www.wto.org/ 25 Jun.

72 See ch V: Transparency and dialogue with civil society, par 176-212.

73 Howse supra n 43; Pauwelyn 2005 JIEL 329-346.

74 Sutherland report, supra n 71 par 211. 
WTO membership should develop a set of clear objectives for the WTO's relationship with civil society and the public at large. ${ }^{75}$ The report discusses the pros and cons of a more formal accreditation system for NGOs. ${ }^{76}$ Doubts are raised whether a formal accreditation system is a worthy investment for the WTO, given the bureaucratic burden; possibly a simple ad hoc registration system could suffice. Furthermore, the report states clearly that

[a]part from the attendance at the plenary sessions of Ministerial meetings every two years, it is unlikely that accreditation would mean the right to observe WTO meetings at first hand. ${ }^{77}$

Regarding the dispute settlement system, the report states that overall there is a sense of satisfaction with the system. The most important underlying assumption is that reform proposals should be approached carefully as no harm must be done to the existing system since it has so many valuable attributes. ${ }^{78}$ However, regarding NGOs handing in amicus curiae briefs, the report states that

those, intimately involved in these proceedings see important need to develop general criteria and procedures at both [the panel and the Appellate Body] levels, to fairly and appropriately handle amicus submissions, balancing worries about resource implications with fairness and a general recognition that such submissions can in some instances improve the overall quality of the dispute settlement process. ${ }^{79}$

Concerning the degree of confidentiality of the dispute settlement proceedings the report acknowledges that this may be damaging to the WTO as an institution. Therefore, the report recommends that the first level panel hearings and Appellate Body hearings should generally be open to the public. Opening up parts of the dispute settlement proceedings to the public is however 
considered to be more complex as this requires consensus among the Member States. ${ }^{80}$

In sum, in the Sutherland report the Consultative Board acknowledged the importance of participation and transparency for the WTO and put forward some interesting proposals. Nevertheless, the general point of view of the WTO towards the relationship with civil society for the future is summed up by stating that

the primary responsibility for engaging civil society in trade policy matters rests with the members themselves. ${ }^{81}$

\subsection{What future steps can the WTO take?}

Even though significant steps have been taken by the WTO in recent years to enhance transparency and the possibilities of participation the organisation does not seem to have taken on the good governance effort in the same manner as other organisations such as the World Bank have. This no doubt is partly the result of the character of the organisation as a member driven organisation. However, as pointed out earlier, the distinctive character does not mean that the WTO does not have an impact on the enjoyment of human rights. In order to create a human rights sensitive environment the organisation needs to do more than it currently does. What steps can the organisation take to further increase respect for the good governance principles of transparency and participation that will help create a climate sensitive to human rights concerns?

\subsubsection{Participation}

A suggestion to improve non-judicial NGO participation would be to actively involve NGOs in the so-called Trade Policy Review Mechanism. As previously 
discussed, the final report reviewing the national policies of a Member State is drawn up by the Trade Policy Review Body, based on the report of the Member State and a report drawn up by the WTO secretariat. The decision on the Trade Policy Review does not refer to any input from NGOs. In this area, the human rights practice can serve as a source of inspiration. Various human rights treaties require states' parties to submit periodic reports. ${ }^{82}$ It is a wellestablished practice for NGOs to submit parallel reports that are accepted and taken into consideration by the human rights monitoring bodies. A similar role can be taken up by NGOs in the Trade Policy Review system. This is necessary as practices in Member States towards human rights violations can severely impact the trading system. ${ }^{83}$

Furthermore, codification of the rules regarding the submission of amicus curiae briefs is long overdue. In light of the fact that WTO panels and the Appellate Body are increasingly confronted with issues beyond the technical aspects of trade liberalisation, expertise input from NGOs on public interest issues should be welcomed. Nevertheless, the case-to-case approach remains in place despite calls from Member States (notably the USA and the European Community) and scholars ${ }^{84}$ to formulate a standard procedure for the acceptance of such submissions. As mentioned earlier, the Sutherland report on the future of the WTO also emphasised the need for general rules.

In the absence of a standardised procedure for amicus curiae briefs the WTO panels and Appellate Body could also seek more NGO input in the form of an

82 For an overview of this practice before the various international human rights bodies see, Jägers 2006 Netherlands Quarterly of Human Rights 229-271.

83 In the early years of GATT trade negotiations were mainly focused on tariff reductions. For the first time non-tariff measures were discussed in the Kennedy Round of 1963-1967. Measures such as dumping or product standards increasingly were considered to have an impact on international trade. Consequently, such non-tariff policies became an integral part of future negotiation rounds. Not surprisingly, some states claimed that different domestic policies regarding labour standards also may lead to unfair competition. To put it bluntly, they were in favour of the inclusion of a so-called 'social clause' in WTO law which would allow states to use trade restrictions against countries where basic workers' rights are not respected because of its impact on international trade.

84 See, ia, the practical suggestions for the use of amicus curiae briefs submitted by Marceau and Stilwell 2001 JIEL 155-187. 
expert opinion especially when confronted with disputes that touch on nontrade issues such as human rights. Besides authorising WTO panels to seek information from any relevant source, article 13 (2) DSU ${ }^{85}$ also authorises WTO panels to consult with experts to obtain their opinion on certain aspects of the matter. This article gives considerable flexibility to WTO panels to involve NGOs that have shown interest in providing information as experts. The authority to seek and accept expert advice is discretionary and in practice WTO panels have requested such contributions in only very few instances. Such expert opinion should also be made public.

A more far-reaching suggestion was made by the International Law Association in 2000 when it recommended that WTO members should

strengthen the rule of law in international trade by enhancing the legitimacy and acceptance of WTO rules by in particular (...) [a]llowing individual parties, both natural and corporate, an advisory locus standi in those dispute settlement procedures where their own rights and interests are affected. ${ }^{86}$

NGOs could play a part in advising whether certain national measures fall within the exceptions of article XX that allow for trade sanctions "necessary to protect human (...) health $(\mathrm{XX} b)$ and 'relating to the products of prison labour" $(X X e)$.

Enhancing public participation in the WTO will further the sustainable development agenda of the WTO. Various international documents such as the Rio Declaration ${ }^{87}$ and Agenda $21^{88}$ have made clear that to achieve sustainable development public participation is a prerequisite

85 Under art 11 (2) of the Agreement on the Application of Sanitary and Phytosanitary Measures Member States are admonished to seek expert opinion. Under art 14, annex 2 of the Agreement on Technical Barriers to Trade they are permitted to do so.

86 ILA Report of the sixty-ninth conference held in London, 25-29 July 2000, Res No 2/2000, annex 3.

87 UN Doc A/CONF/151/26 (Vol 1); 31 ILM 874 (1992).

88 UN GAOR $46^{\text {th }}$ session, agenda item 21 , UN Doc A/COLNF/151/26 (1992). 


\subsubsection{Transparency}

What steps can the WTO take to further increase transparency within the organisation?

As stated earlier, the influence of specific individuals and the secretariat on the agenda of trade liberalisation is considerable. It has been suggested that more transparent processes might be required for the appointment of seniors in the secretariat and the Appellate Body. ${ }^{89}$ Moreover, as acknowledged by the Consultative Board in the Sutherland report the dispute settlement proceedings need to be opened up to the public as far as possible. Currently, this is only possible at the explicit request of Member States as occurred in the ECHormones dispute and the Measures affecting Large Civil Aircraft case. It is likely that cases between the EC and the $\mathrm{US}^{90}$ will be more open to the public in the future as these members are strong supporters of transparency. Other WTO Member States, however, remain very opposed to opening up proceedings. It is desirable that WTO Member States find agreement on this issue making it a rule rather than the exception. Transparency in judicial proceedings in the sense of being open to the public is considered a necessity both at the national and the international level. There is no reason why the WTO should treat it judicial disputes any differently.

The suggestions mentioned here illustrate possible ways in which the WTO can further improve its transparency and the possibilities for participation. It is clear that trade negotiations up to a point require certain confidentiality and in practice therefore limits will be set to the amount of openness possible. Moreover, increasing avenues of participation for non-state entities such as NGOs brings with it important questions concerning their legitimacy and accountability. It is beyond the scope of this article to address these vital

89 Howse supra $\mathrm{n} 43$ at 882.

90 These two WTO members make the most frequent use of the dispute settlement system. 
issues ${ }^{91}$ suffice it to say that many other international organisations have been successful in addressing these issues and incorporating a significant role for NGOs into their procedures without threatening the intergovernmental character of their organisations. ${ }^{92}$

\section{Conclusion}

The WTO has been the focal point of anti-globalisation critique claiming the detrimental effect of the activities of the organisation for the protection and enjoyment of human rights. To a certain extent this critique is based on misconceptions about the role of the organisation. Compared to other international organisations the WTO hardly operates independently from its Member States. Although it cannot be denied that it has some autonomous powers, the organisation as such does not directly violate human rights for which it can be held accountable. Nevertheless, its activities may have human rights implications. In the light of this, we discussed the WTO dispute settlement mechanism, the Trade Policy Review Mechanism and technical assistance. From a legal perspective, only the former may have a direct impact on domestic state policies for the protection of human rights because it may require a state to adapt certain trade related human rights policies. Evidently, it primarily concerns policies for the protection of human rights (say, the right to health) within a state's own jurisdiction. Yet, it has also been illustrated that it is feasible that the WTO dispute settlement mechanism at some point will be asked to rule on the lawfulness of trade restrictions for the protection of human rights elsewhere. This shows that human rights considerations are of particular relevance for the dispute settlement mechanism. Human rights considerations, however, may also be relevant for activities that do not bind the Member States

91 There is abundant literature on the issue of legitimacy of NGOs. See, ia, Bluemel 2004 Brook J Int'l L 139; Edwards and Zadek Governing 200-224; Slim By What Authority; Charnovitz 2004 JIEL 675-682.

92 Jägers supra $\mathrm{n} 82$. 
and may have a normative impact such as the Trade Policy Review Mechanism and technical assistance.

It is here where principles of good governance can play an important role. Serious deficiencies in the field of transparency and participation in the past have contributed to suspicion and hostility that the organisation has encountered. The tide of good governance has, however, not completely bypassed the WTO. In recent years the organisation has taken significant steps to enhance its transparency and the possibility for participation by non-state entities. Nevertheless, a lot remains to be done to help secure a human rights responsive environment within the WTO.

The need is all the greater in the dispute settlement mechanism as it is more than likely that the WTO will be confronted with more difficult and controversial cases also involving human rights issues. There is, therefore, an everincreasing need for transparency and greater participation in these proceedings by actors representing such issues.

Future developments as suggested in this article will help, on the one hand ensure that the WTO does not pose an obstacle in the realisation of human rights, and on the other hand help sensitise the organisation for human rights considerations. 


\section{Bibliography}

Alston and Tomasevski (eds) Right to Food

Alston P and Tomasevski K (eds) The Right to Food: International Studies in Human Rights (Martinus Nijhoff Utrecht 1984)

Amerasinghe Principles

Amerasinghe CF Principles of the Institutional Law of International

Organizations (Cambridge University Press Cambridge 1996)

Bluemel 2004 Brook J Int'I L

Bluemel EB "Overcoming NGO accountability in international governance" 2004 (31) Brooklyn Journal of International Law 139

Cassese International Law

Cassese A International Law (Oxford University Press New York 2001)

Charnovitz 1996 U PA J Int'l Econ L

Charnovitz S "Participation of Non-Governmental Organizations in the World Trade Organization" 1996 (17) University of Pennsylvania Journal of International Economic Law 331-357

Charnovitz 1998 Virg J of Int'l L

Charnovitz S "The Moral Exception in Trade Policy" 1998 (38) Virginia Journal of International Law 689-746

Charnovitz 2000 Fordham Int'l LJ

Charnovitz S “Opening the WTO to Nongovernmental Interests' 2000 (24)

Fordham International Law Journal 173-216

Charnovitz 2004 JIEL

Charnovitz S "The WTO and Cosmopolitics" 2004 (7) Journal of International Economic Law 675-682 
Crawford Third Report on State Responsibility 14

Crawford J Third Report on State Responsibility addendum 4 August 2000 A/CN 4/507/Add4

Edwards and Zadek Governing 200-224

Edwards M and Zadek S "Governing the Provision of Global Public Goods: The Role and Legitimacy of Nonstate Actors" in Kaul I et al (eds) Providing Public Goods: Managing Globalization (Oxford University Press Oxford 2003)

Eide Right to Adequate Food

Eide A The Right to Adequate Food as a Human Right (United Nations Center for Human Rights Geneva 1987)

Gattini 2002 Eur J Int'l L

Gattini A "A Return Ticket to 'Communitarisme' Please" 2002 (13)

European Journal of International Law 1181-1199

Hoekman and Kostecki Political Economy

Hoekman B and Kostecki M The Political Economy of the World Trading System (Oxford University Press New York 1995)

Howse 2003 Eur LJ

Howse R "Membership and its Privileges: The WTO, Civil Society, and the Amicus Brief Controversy" 2003 (9) European Law Journal 496-510

Howse 2004 Rutgers L Rev

Howse R "For a Citizen's Task Force on the Future of the World Trade Organization" 2004 (56) Rutgers Law Review 877-884 


\section{ILA Report}

International Law Association Report of the sixty-ninth conference held in London 25-29 July 2000 Resolution No 2/2000

Jägers 2006 Netherlands Quarterly of Human Rights

Jägers NMCP "Mainstreaming Human Rights in International Economic Organisations: Improving Judicial Access for NGOs to the World Trade Organization" 2006 (24) Netherlands Quarterly of Human Rights 229-271

Jägers Corporate Human Rights Obligations

Jägers NMCP Corporate Human Rights Obligations: in Search of Accountability (Intersentia Antwerp 2002)

Kamminga Evolving Status of NGOs

Kamminga MT "The Evolving Status of NGOs under International Law: A Threat to the Inter-State System?" in Alston P (ed) Non-State Actors and Human Rights (Oxford University Press Oxford 2005)

Loy Public Participation 116

Loy F "Public Participation in the World Trade Organization" in Sampson GP (ed) The Role of the World Trade Organization in Global Governance (United Nations University Press Hong Kong 2001)

Maastricht Guidelines 1998 Human Rights Quarterly Maastricht Guidelines "The Maastricht Guidelines on Violations of Economic, Social and Cultural Rights" 1998 (20) Human Rights Quarterly 691-705

Marceau and Stilwell 2001 JIEL

Marceau G and Stilwell M "Practical suggestions for Amicus Curiae briefs before WTO adjudicating bodies" 2001 (4) Journal of international Economic Law 155-187 
Maupain Upholding Workers' Rights 85-142

Maupain F "Is the ILO Effective in Upholding Workers' Rights? Reflections on the Myanmar Experience" in Alston P (ed) Labour Rights as Human Rights (Oxford University Press New York 2005)

Oloka-Onyango and Udagama Economic, Social and Cultural Rights Oloka-Onyango $\mathrm{J}$ and Udagama $\mathrm{D}$ The realization of Economic, Social and Cultural Rights: Globalization and its Impact on the Full Enjoyment of Human Rights: Preliminary Report Doc E/CN4/Sub2/2000/13 of 15 June 2000 (Commission on Human Rights Geneva 2000)

Pauwelyn 2005 JIEL

Pauwelyn J "The Sutherland report: A missed opportunity for genuine debate on trade, globalization and reforming the WTO" 2005 (8) Journal of International Economic Law 329-346

Pauwelyn Conflict of Norms

Pauwelyn J Conflict of Norms in Public International Law (Cambridge University Press Cambridge 2003)

Reinisch and Irgel 2001 Non-State Actors and International Law Reinisch A and Irgel C "The participation on Non-Governmental Organisations in the WTO Dispute Settlement system" 2001 (1) Non-State Actors and International Law 127-151

Schaffer Defending Interests

Schaffer GC Defending Interests (Brookings Institution Press Washington DC 2003)

Shue Basic Rights

Shue H Basic Rights: Subsistence, Affluence, and U.S. Foreign Policy (Princeton University Press Princeton NJ 1980) 
Skogly Human rights obligations

Skogly SI The human rights obligations of the World Bank and the International Monetary Fund (Cavendish London 2001)

Slim By What Authority

Slim H By What Authority? The Legitimacy and Accountability of Non Governmental Organisations (International Council on Human Rights Policy Oxford 2002)

Van den Bossche Hoe kan het beter?

Van den Bossche P Hoe kan het beter? Preventie van handelsoorlogen en geschillenbeslechting door de Wereldhandelsorganisatie: Oratie (Maastricht University The Netherlands 27 September 2002)

Vandaele International Labour Rights Vandaele A International Labour Rights and the Social Clause: Friends or Foes (Cameron May London 2005)

Vázquez 2003 JIEL

Vázquez CM "Trade Sanctions and Human Rights - Past, Present, and Future" 2003 (6) Journal of International Economic Law 797-839

Willetts Representation of private organizations 53 Willetts $\mathrm{P}$ "Representation of private organizations in the global diplomacy of economic policy-making" in Karsten R and Schneider V (eds) Private Organizations in Global Politics (Routledge London 2000)

World Bank Governance

World Bank Governance: The World Bank's Experience (World Bank Washington DC 1994)

\section{Register of legislation}


Burmese Freedom and Democracy Act HR 2330, 2003

\section{Register of court cases}

ICJ Legal Consequences of the Construction of a Wall in the Occupied Palestinian Territory Advisory Opinion 9 July 2004 [Found on internet] http://www.ici-cii.org/icjwww/idocket/imwp/imwp advisory opinion/ imwp advisory opinion 20040709.htm [Date of use 12 January 2007] National Foreign Trade Council v Baker 26 F Supp 2d 287, 291 (Mass 1998) WTO Doc WT/DS138/AB/R United States - Imposition of Countervailing Duties on Certain Hot-Rolled Lead and Bismuth Carbon Steel Products originating in the United Kingdom 7 June 2000 DSR 2000:V 2601

WTO Doc WT/DS246/AB/R European Communities - Conditions for Granting of tariff Preferences to Developing Countries Appellate Body report 20 April 2004

WTO Doc WT/DS277/R Soft Wood Lumber Case Report of the Panel 22 March 2004

WTO Doc WT/DS316 United States- Measures affecting Trade in Large Civil Aircraft 20-21 March 2007

WTO Doc WT/DS320 United States - Continued Suspension of Obligations in the EC-Hormones Dispute 27-28 September 2006, 2-3 October 2006

WTO Doc WT/DS58/AB/R Shrimp/Turtle Case Report of the Appellate Body12 October 1998

WTO Doc WT/DS58/R United States - Import Prohibition of Certain Shrimp and Shrimp Products Report of the Panel 15 May, 1998

WTO Doc WT/DS88/1 United States - Measure affecting government procurement: request for consultations by the European Communities 26 June 1997

\section{Register of international treaties and documents}

GATT Decision on Differential and More Favourable Treatment, Reciprocity and Fuller Participation of Developing Countries 1979 Marrakesh Agreement establishing the World Trade Organization 1995 
Resolution Concerning the Measures Recommended by the Governing Body under Article 33 of the ILO Constitution on the Subject of Myanmar 2000

\section{Register of Internet resources}

3Dthree http://www.3dthree.org/ 22 Jun

3Dthree US and EU Cotton Production and Export Policies and Their Impact on West and Central Africa: Coming to Grips with International Human Rights Obligations 2004 [Found on internet] http://www.3dthree.org/pdf 3D/1404-EGICottonBrief FINAL.pdf [Date of use 22 June 2008]

Commission of the European Communities http://eur-lex.europa.eu/ 24 Jun Commission of the European Communities European Governance: A White Paper COM 2001428 [Found on internet] http://eur-lex.europa.eu/LexUri Serv/site/en/com/2001/com2001 0428en01.pdf [Date of use 24 June 2008]

Commission on Human Rights http://www.unhchr.ch/ 24 Jun Commission on Human Rights The role of good governance in the promotion of human rights Resolution 2000/64 [Found on internet] http://www.unhchr.ch/huridocda/huridoca.nsf/(Symbol)/E.CN.4.RES.2000.6 4.En?Opendocument [Date of use 24 June 2008]

Sutherland et al http://www.wto.org/ 25 Jun Sutherland $\mathrm{P}$ et al The Future of the WTO. Addressing institutional challenges in the new millennium (World Trade Organization Geneva 2004) [Found on internet] http://www.wto.org/english/thewto e/10anniv e/ future wto e.pdf [Date of use 25 June 2008]

UN http://untreaty.un.org/ 7 May

UN Draft Articles on Responsibility of States for Internationally Wrongful Acts with commentaries 2001 [Found on internet] http://untreaty.un.org/ 
ilc/texts/instruments/english/commentaries/9 6 2001.pdf [Date of use 7 May 2007]

UNESCAP http://www.unescap.org/ 16 Jun

United Nations Economic and Social Commission for Asia and the Pacific What is Good Governance? [Found on internet] http://www.unescap.org/pdd/prs/ProjectActivities/Ongoing/gg/governance.a $\underline{\text { sp }}$ [Date of use 16 June 2008]

WTO http://www.wto.org/ 22 Jun

WTO Understanding the WTO: Developing Countries WTO technical cooperation [Found on internet] http://www.wto.org/english/thewto e/whatis e/tif e/dev3 e.htm [Date of use 22 June 2008]

WTO http://www.wto.org/ 4 May

World Trade Organisation Understanding the WTO [Found on internet] http://www.wto.org/english/thewto e/whatis e/tif e/understanding e.doc [Date of use 4 May 2007]

\section{List of abbreviations}

art article(s)

ASR Articles on State Responsibility

ch chapter(s)

DSB Dispute Settlement Body

DSU Dispute Settlement Understanding

GATT General Agreement on Tariffs and Trade

GSP General System of Preferences

ICFTU International Confederation of Free Trade Unions

ILC International Law Commission

IMF International Monetary Fund

ITO International Trade Organization

NFTC National Foreign Trade Council 


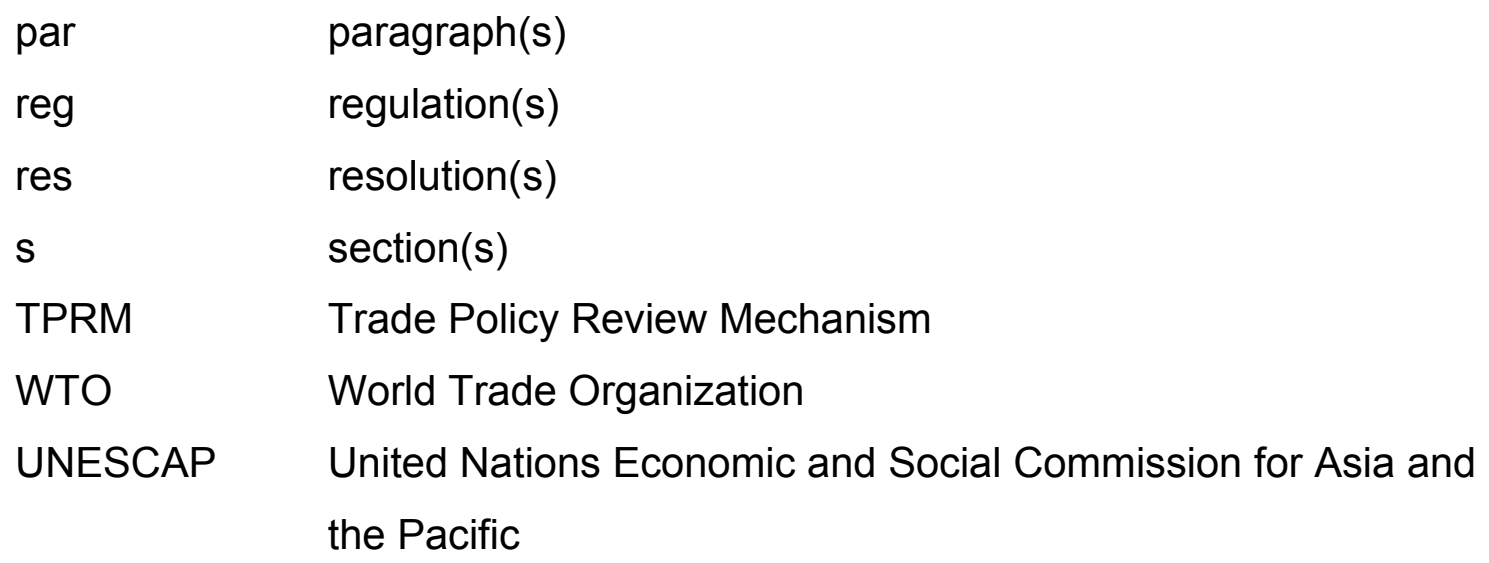

